\title{
The Sustainable Development Goals, Organizational Learning and Efficient Resource Management in Construction
}

\author{
Dr Alex Opoku"*, alex.opoku@ucl.ac.uk \\ Prof Vian Ahmed ${ }^{2}$, vahmed@aus.edu \\ Prof George Ofori ${ }^{3}$, oforig3@lsbu.ac.uk \\ ${ }^{1}$ Bartlett School of Construction \& Project Management, University College London \\ ${ }^{2}$ Department of Industrial Engineering, American University of Sharjah, UAE \\ ${ }^{3}$ School of Built Environment \& Architecture, London South Bank University \\ *Managing Guest Editor
}

The universal adoption of the 2030 Agenda for Sustainable Development which set out 17 Sustainable Development Goals (SDGs), 169 targets and underpinned by 231 indicators is one major initiative towards socio-economic development globally. The construction industry has a critical role to play in a achieving the SDGs. For example, construction and demolition activities generate large volumes of waste and this requires the adoption of practices that will reduce waste generated and maximise re-use with the aim of improving efficient resource use and reduce negative impact on the environment (Galvez-Martos et al., 2018).

The construction industry as a sector has the opportunity to influence the realisation of the SDGs by formulating policies and regulatory frameworks that drive the adoption of sustainable construction practices. Mahpour (2018) argues that the circular economy is a sustainable concept that could be adopted for the efficient exploitation of resources and the management of construction and demolition waste. The adoption of sustainable construction could greatly help the realisation of a number of SDGs including SDG2 (End Hunger), SDG3 (Good Health \& Well-Being), SDG4 (Quality education), SDG6 (Clean Water \& Sanitation), SDG7 (Affordable \& Clean Energy), SDG8 (Decent Work \& Economic Growth), SDG9 (Industry, Innovation \& Infrastructure), SDG10 (Reduced Inequalities), SDG11 (Sustainable Cities \& Communities), and SDG13 (Climate Action) (Opoku, 2016).

The link between organizational learning and sustainability is receiving an increasing amount of attention in construction management research and practice (Opoku and Fortune, 2011). Organizational learning has been defined by Lopez et al. (2005) as the process of creating, acquiring and integrating knowledge with the aim of developing resources and capabilities that contribute to organizational performance. Opoku and Fortune (2011) argue that the ability of construction organizations to cope with the journey towards a sustainable change requires organizational learning. It is essential that construction organizations engage in organizational learning methods that embraces sustainability and innovation. Existing organizational learning methods in the construction industry such as Post Project Review (PPR) and Post Occupancy Evaluations (POE) mostly focuses on technical issues instead of the social, economic and environmental impact of the completed project. 
This special Issue seeks to explore the link between the SDGs, organizational learning and efficient resource management in construction. Topics may include but not limited to the following focusing on the construction industry;

- $\quad$ Sustainable construction \& SDGs

- Sustainable supply chain management

- The role of business in achieving the SDGs

- Organizational learning and sustainability

- Sustainable procurement

- Construction \& demolition waste management

- Construction resource management

- Sustainable consumption of materials \& resources

- Construction and the circular economy

- Green business models in construction

- Facilities management and the SDGs

\section{Manuscript Preparation and Submission}

A Virtual Special Issue (VSI) is an online-only grouping of Special Issue articles traditionally assigned to a single Special Issue. The articles in a VSI will be assigned a unique identifier and published in a regular journal issue. The unique identifier allows to simultaneously adding the article to a VSI in ScienceDirect.com. Articles grouped together in a VSI retain their original citation details. A VSI speeds up the publication of individual articles as, unlike the publication process for conventional Special Issue articles, a VSI does not need to wait for the final article to be ready before publication. A detailed submission guideline is available as "Guide for Authors" at:

http://www.journals.elsevier.com/resources-conservation-and-recycling. All manuscripts and any supplementary material should be submitted through Elsevier Editorial System (http://ees.elsevier.com/recycl). The authors must select "SI: Construction \& SDGs" in the submission process.

Note: EOI and abstract should be submitted to Dr Alex Opoku (alex.opoku@ucl.ac.uk) in the first instance for review and approval before submitting a full paper through the Elsevier Editorial System. Approval of abstract does not guarantee the full paper will be sent out for peer review.

\section{Important Dates}

- Abstract submission: $31^{\text {st }}$ July 2020

- Notification of accepted abstract: $21^{\text {st }}$ August 2020

- Full paper submission deadline: $30^{\text {th }}$ December 2020

- Final decision notification: 30 October 2021

- Publication: As soon as accepted (VSI) 


\section{References}

1. Gálvez-Martos, J-L., David Styles, D., Schoenberger, H., and Zeschmar-Lahl, D. (2018), Construction and demolition waste best management practice in Europe, Resources, Conservation \& Recycling, 136, 166-178

2. Lopez, S P., Peon, J M. and Ordas, C J V. (2005), Organizational learning as a determining factor in business performance, The Learning Organization, 12 (3), 227-245

3. Mahpour, A. (2018), Prioritizing barriers to adopt circular economy in construction and demolition waste management, Resources, Conservation \& Recycling, 134, 216-227

4. Opoku, A. (2016), SDG2030: A Sustainable Built Environment's Role in Achieving the Post-2015 United Nations Sustainable Development Goals. In: Chan, P W and Neilson, C J (Eds.), Proceedings 32nd Annual ARCOM Conference, 5-7 September 2016, Manchester UK. Association of Researchers in Construction Management, 1101-1110

5. Opoku, A. and Fortune, C. (2011), Organizational learning and sustainability in the construction industry, The Built \& Human Environment Review, Vol. 4, Special Issue 1, (2011) [Online], pp.98-107 